\title{
4 African Initiated Churches and development from below
}

\author{
Subjecting a thesis to closer scrutiny
}

\author{
Ignatius Swart
}

\section{Introduction}

In the burgeoning academic scholarship on religion and development, most specifically that section concerned with the nexus between religion and development in African society, the potential and actual development role of African Initiated Churches (AICs) - or what some scholars would like to refer to in the collective sense as 'African Independent faith' (Schlemmer 2008, 19), '(African) Independent Christianity' (Bompani 2010), or 'African Christianities' (Adogame 2016) - is receiving increasing attention. In this respect, a very specific theoretical claim or thesis that has come into vogue in the literature to capture the essential contribution that these churches are making in the sphere of development is that of development from below. By adopting this thesis scholars are advancing an elaborate argument about a mode of development that - in terms of process, agency and outcome - can be proffered as a counterpoint to a development dynamic from above driven by the state and international development agencies. In the wake of the failure of these institutions to bring about sustainable and lasting development outcomes in poor African communities, AICs are increasingly appreciated as emerging catalysts of endogenous, popular, or grass-roots development that may even have the potential to ripple outwards to become the driving force of an 'African Renaissance' (Bernstein and Rule 2010, 126). In effect, development is here perceived as a dynamic whereby local people and groups are not only taking charge of their own development, but whereby the interrelated religious and cultural dimensions of their life worlds become important mediating factors in terms of improving the nature and outcome of their development (Adogame 2016, 2-3).

This chapter seeks to contribute to the academic debate about the AICs and development by subjecting the development-from-below thesis to closer scrutiny. With this aim in mind, it is important to mention that the chapter has been written within the collaborative framework provided by the Research Programme on Religious Communities and Sustainable Development at Humboldt-Universität zu Berlin and the programme's latest research project on the 'Potentials of Cooperation with African Initiated Churches for Sustainable 


\section{Ignatius Swart}

Development'. As such, the chapter wants to acknowledge that the spectrum of churches included in contributions to the development-from-below thesis has been well accommodated by the operational definition of AICs advanced by the programme and project. In this definition, for which the Berlin-based researchers find important direct support in the work of African scholars such as John Pobee and Gabriel Ositelu, AICs 'denote all churches founded by Africans, in Africa and without direct links to "Missionary godfathers"' (Öhlmann, Frost, and Gräb 2016, 2). By implication, this definition therefore makes it possible and justifiable for the Berlin group to include the familiar African Independenttype Churches (Zionist, Apostolic, and Ethiopian) and what have become known as the new African-founded Pentecostal-Charismatic Churches (PCCs) in an integrated research focus (Öhlmann et al. 2016; Öhlmann, Frost, and Gräb 2017). Moreover, while they acknowledge that this aggregation cannot ignore 'the substantial heterogeneity' of the churches involved, they nevertheless argue that a number of common features can be identified to justify such incorporation. This includes the fact that both these groups 'fall into the definition of African initiated' that, unlike many mainline or missionary churches, can 'with very few exceptions' not yet be considered 'partners of international development agencies' (Öhlmann et al. 2016, 2). But perhaps most importantly, it also includes the way in which both groups adopt a similar spiritual worldview dominated by a belief in the Holy Spirit, spiritual forces and the importance of healing (ibid.).

As already suggested, this chapter finds particular support for its own explorative framework through the way in which both the familiar African Independenttype Churches and the new African-founded PCCs are presented in the literature as exponents of the dynamics of development from below. Thus, whereas discussions of the development-from-below thesis may in certain cases still offer separate perspectives on these two groups of churches as exponents of development from below, the more important point is that both groups are not only valued in terms of this thesis, but that this valuation is often done in a way that resonates with the 'blurred typological distinction' (Meyer 2004, 452; see also Schlemmer 2008, 25-26) between the two groups. From this vantage point, this chapter now identifies and discusses five dimensions that can be said to define the theoretical claim of the dynamics of development from below in the literature on AICs and development. The chapter then concludes with a critical evaluation of the thesis by considering the promises, but importantly also the challenges and limitations, the thesis may hold for an ongoing research focus on AICs and development. This more specifically entails that the chapter finds undoubted promise in deepening a research exploration of AICs and development along the lines of the development-from-below thesis identified in this chapter. Yet, it at the same time also entails that the chapter finds it necessary to qualify this promise by identifying with the synergistic approach in the development studies literature, which highlights the fundamental importance of a synergistic relationship between bottom-up and top-down processes of development to achieve broad-based development. 


\section{Dimensions of the development-from-below thesis}

This chapter's identification of distinctive dimensions of the development-frombelow thesis in the literature on AICs and development does not imply that other readings of the selected material may not lead to additional or different identifications and formulations related to this thesis. Accordingly, it is also not suggested that the selected corpus of material on which the present identification is based (see the overview presented in Table 4.1) cannot be expanded by additional discoveries of relevant material. From this vantage point, this chapter depends on a corpus of literature that its author has within the constraints of available time and resources been able to identify and study. This necessarily leads to the acknowledgement that the chapter, for the purpose of its analytic undertaking, relies on a corpus of material that is strongly dominated by contributions from the South African context. While it can therefore rightly be argued that there is an important need to strengthen the wider African focus in this chapter in an anticipated further exploration of the topical focus, this identification is not seen to devalue the meaningfulness of the present undertaking to begin to learn how a particular thesis is seemingly giving ongoing shape to academic debates about the group of churches focused upon in this chapter.

Against this backdrop, in the following discussion five distinctive clusters of ideas and perspectives are presented that can be considered as comprehensive in terms of their capturing of essential dimensions across the respective literature. By way of orientation, readers are again referred to Table 4.1 and the summary it presents of the following three indicators across the respective literature: (1) paraphrasing of the development-from-below idea; (2) the AICs involved in the development of this idea (African Independent Churches and/or PCCs); and (3) the research location and type of research undertaken.

\section{Development from below as a desecularised catchphrase or idea}

In view of a closer encounter with the development-from-below thesis in the literature on AICs and development, it becomes important to note from the outset that development from below constitutes a catchphrase or idea that is not original to the debate on religion and development. As a distinctive catchphrase or idea, development from below has its origins in international development studies discourse dating back as far as the late 1960s when, because of a growing disillusionment with the dominant modernisation model of development and its accompanying 'top-down' or 'trickle down' approach to economic development, the need arose for the conceptualisation of an alternative development model (Sanyal 1998; Stöhr 1980). Accordingly, it is within this framework that the idea of development from below emerged as a counterpoint to what was otherwise labelled as development from above (Stöhr 1980, 1-3).

In his particularly useful outline of the historical evolution of development from below as an idea complex, Bishwapriya Sanyal points out how the idea drew intellectual strength from both neoclassical economic and neo-Marxist 
Table 4.1 Overview of literature capturing the development-from-below thesis

\begin{tabular}{|c|c|c|c|}
\hline Selected literature1 & $\begin{array}{l}\text { Paraphrase of the development-from- } \\
\text { below idea }\end{array}$ & AICs involved & $\begin{array}{l}\text { Research location and type of } \\
\text { research }\end{array}$ \\
\hline $\begin{array}{l}\text { Robert C. Garner. 2000. 'Religion as Source of } \\
\text { Social Change in the New South Africa'. (journal } \\
\text { article) }\end{array}$ & social change from below & $\begin{array}{l}\text { African Independent } \\
\text { Churches and PCCs }\end{array}$ & $\begin{array}{l}\text { Empirical research in Edenvale } \\
\text { township, KwaZulu-Natal, } \\
\text { South Africa }\end{array}$ \\
\hline $\begin{array}{l}\text { Lawrence Schlemmer. 2008. Dormant Capital: } \\
\text { Pentecostalism in South Africa and its Potential Social } \\
\text { and Economic Role. (research report) }\end{array}$ & development from below & $\begin{array}{l}\text { African Independent } \\
\text { Churches and PCCs }\end{array}$ & $\begin{array}{l}\text { Empirical research in various } \\
\text { locations in South Africa \& } \\
\text { literature research }\end{array}$ \\
\hline $\begin{array}{l}\text { Barbara Bompani. 2008. 'African Independent } \\
\text { Churches in Post-Apartheid South Africa: New } \\
\text { Political Interpretations'. (journal article) }\end{array}$ & politics from below & $\begin{array}{l}\text { African Independent } \\
\text { Churches }\end{array}$ & $\begin{array}{l}\text { Empirical research in Jabulani, } \\
\text { north-west Soweto, South } \\
\text { Africa }\end{array}$ \\
\hline $\begin{array}{l}\text { Barbara Bompani. 2010. 'Religion and } \\
\text { Development from Below: Independent } \\
\text { Christianity in South Africa'. (journal article) }\end{array}$ & development from below & $\begin{array}{l}\text { African Independent } \\
\text { Churches }\end{array}$ & $\begin{array}{l}\text { Empirical research in Jabulani, } \\
\text { north-west Soweto, South } \\
\text { Africa }\end{array}$ \\
\hline $\begin{array}{l}\text { Barbara Bompani and Maria Frahm-Arp, eds. } \\
\text { 2010. Development and Politics from Below: } \\
\text { Exploring Religious Spaces in the African State. } \\
\text { (anthology) }\end{array}$ & development and politics from below & $\begin{array}{l}\text { African Independent } \\
\text { Churches and PCCs }\end{array}$ & $\begin{array}{l}\text { Empirical and theoretical } \\
\text { research related to different } \\
\text { countries in sub-Saharan } \\
\text { Africa }\end{array}$ \\
\hline $\begin{array}{l}\text { Ann Bernstein and Stephen Rule. 2010. 'Flying } \\
\text { under South Africa's Radar: The Growth and }\end{array}$ & $\begin{array}{l}\text { PCCs depicted as 'bottom-up } \\
\text { phenomena' that can become drivers }\end{array}$ & PCCs & $\begin{array}{l}\text { Empirical research in various } \\
\text { locations in South Africa }\end{array}$ \\
\hline
\end{tabular}
Impact of Pentecostals in a Developing Country'. (book chapter) phenomena' that can become drivers
of an African Renaissance
African Independent Empirical research in Edenvale township, KwaZulu-Natal,

African Independent Empirical research in various Churches and PCCs locations in South Africa \&

African Independent Empirical research in Jabulani, Churches north-west Soweto, South

African Independent Empirical research in Jabulani, Churches north-west Soweto, South

African Independent Empirical and theoretical research related to different Africa locations in South Africa 
Barbara Bompani. 2015. 'Religion and Development in Sub-Saharan Africa: An Overview'. (book chapter)

Dena Freeman. 2015. 'Pentecostalism and Economic Development in Sub-Saharan Africa'. (book chapter)

Afe Adogame. 2016. 'African Christianities and the Politics of Development from Below'. (journal article)

Philipp Öhlmann, Marie-Luise Frost, and Wilhelm Gräb. 2016. 'African Initiated Churches' Potential as Development Actors'. (journal article)

Philipp Öhlmann, Marie-Luise Frost, and Wilhelm Gräb. 2017. 'African Initiated Churches' and sustainable development in South Africa potentials and perspectives'. (discussion paper)
African Independent Churches depicted as representatives of a 'development ethos' that promotes local community initiatives

PCCs depicted as catalysts of a 'transformation of behaviour' that can lead to upward socioeconomic mobility

politics of development from below, PCCs development from below

AICs' rootedness in communities makes them actual and potential development actors
African Independent Empirically informed

Churches and PCCs theoretical research relevant to the sub-Saharan African region

PCCs Empirically informed

theoretical research relevant to the sub-Saharan African region

Theoretical research and ethnographic research of RCCG in Nigeria

African Independent Empirical research in the Churches and PCCs Gauteng and Limpopo provinces of South Africa

AICs' activities depicted as starting at African Independent the micro and meso levels of society holding potential for ecological

Churches and PCCs

Empirical research in the northern provinces of South Africa

Note

1 See the reference list at the end of this chapter for the full bibliographical details of the selected literature in this table. 
critiques of the mainstream development paradigm in the period under discussion. Albeit from widely opposite ideological positions, the two intellectual streams were unified in their similar critical biases against 'all dominant institutions at the top' and particularly targeted the state as the root cause of the failures of development (Sanyal 1998, 4, 5). In turn, through the intellectual climate created by the different strands of critique, development from below consequently emerged as the label for a 'new, conceptually eclectic approach' (ibid., 5) that resonated with both strands. In the case of neoclassical economic argumentation, proponents of this approach could especially relate, in opposition to conventional state policies, to arguments that wanted to give precedence to the efficiency of small farmers and micro-businesses over big farmers and large businesses in promoting grass-roots economic development (ibid.). Conversely, in the case of neo-Marxist argumentation, proponents of the approach felt equally attracted to arguments that the economic and political interests of the poor would be better served by projects and policies steered towards 'autonomous development effort at the bottom', disconnected from the exploitative tendencies of 'institutions at the top' (ibid., 5-6). Taken together, this all boiled down to the conviction that aspirations for development were best served by 'efforts at the bottom by people themselves for generating income and employment and for political mobilization' (ibid., 6; cf. Stöhr 1980, 8).

Following from the very concise historical perspective provided so far, it becomes important to note how a longer history of the conceptual and theoretical evolution of the idea of development from below has given direction to various theoretical strands of a so-called alternative development paradigm that were promoted in international debates about development in the 1980s and 1990s. Significantly, this included theoretical developments labelled 'people-centred development', 'popular development', 'people's self-development', 'autonomous development', and 'participatory development' (see e.g. Brohman 1996; Carmen 1996; Korten 1990; Rahman 1993). But equally significant from an agency perspective, it also included substantial intellectual investment in the development of a cross-cutting debate about non-governmental organisations (NGOs) as preferred catalysts of the ideal of development from below and its various conceptual expressions (see e.g. Brohman 1996, 253-7; Korten 1990). In the words of Sanyal (1998, 2), with regard to this preference for the agency role of NGOs (in the wake of a strong anti-state sentiment in relation to development agency):

There were many arguments in support of NGOs ... I want to point out the crucial assumption underlying these arguments: that NGOs are particularly appropriate agents for fostering development from below because their organizational priorities and procedures are diametrically opposite to those of the institutions at the top. Unlike state and market institutions, which are driven by the need for social control and profit, NGOs are interested primarily in building communities ... NGOs, unlike the state, neither rely upon coercive forces nor adopt profit-seeking mechanisms, as is customary for market institutions. Rather, NGOs rely solely on solidarity bondings in 
civil society; and this solidarity is nurtured through decentralized and participatory decision making supported by voluntary local efforts.

This observation about NGOs as preferred agents of the dynamics of development from below subsequently brings us to an essential point in the discussion. Whereas authors from the selected literature on AICs and development find little need to relate their own argumentation to the one about NGOs, the implication is nevertheless that in the debate about AICs and development, these churches have replaced secular NGOs as the preferred agents of the dynamics of development from below. Moreover, when considered in terms of NGO organisational theory, AICs could according to this appreciation as developmentfrom-below agents even be seen as surpassing NGOs' role as 'third-party' organisations that operate on behalf of people's interests (see the quote from Sanyal's discussion above). Instead, they could be seen as taking on the role of 'first-party' organisations that embody people's direct participation in events (Korten 1990, 100-102).

Consequently, in the selected literature an image of AICs as people's organisations strongly emerges from the way in which they are depicted as flourishing institutions on the ground. In contrast to the inability of other institutional formations (not least the state's) to do so, they are depicted in people's organisational mode as successful in the way in which they become fundamental in accommodating poor (but also middle-class) people's 'everyday lived experiences' (Adogame 2016, 2) that incorporate both the spiritual and worldly dimensions as an integrated whole (Adogame 2016, 1-3; Bompani 2010, 309; Bompani and Frahm-Arp 2010b, 2). For an author such as Barbara Bompani, who focused her empirical research on African Independent Churches in South Africa, it is AICs' 'life-enhancing activities' (Bompani 2010, 309) that make them so attractive to their followers. African Independent Churches, she argues, become 'communities in which people can rely on strong ties within the religious network and fully participate in both spiritual and earthly activities' (ibid., italics added). And it is from this vantage point, she further argues, that these churches have shown a proven ability to respond to both the spiritual and tangible 'insecurities' of their followers. Whereas the former insecurities pertain to their need for protection against evil forces (which are perceived as real in African cosmology), the latter very specifically involve the socioeconomic dimensions of their lives and their own active participation in them:

Especially in the post-apartheid context, AICs offer concrete resources (alongside their religious inputs) that attract new believers. AICs are involved in important economic activities such as savings clubs, lending societies ... and burial societies that encompass millions of South African rand. These communities play a strong and supportive role among black Africans in a deprived economic situation in which there are few other development agencies or organisations operating on a wider scale.

(Bompani 2010, 310; cf. Bompani 2015, 106) 
It follows that for some authors (noticeably from the Berlin group) it has therefore become important to allude to the holistic view that guides AIC members' understanding of development, not least among their leadership. According to this view, there is an insistence among AIC leadership that the spiritual dimension of people's lives belongs inseparably to a wider, comprehensive understanding of development that also constitutes social and material dimensions. For AIC leaders, it is therefore the task of their churches to support their members in all these areas, in order to 'change' or develop 'the whole person' (Freeman 2015, 117; Öhlmann et al. 2016, 5, 10, 2017, 4, 9).

Based on such insistence on understanding development in a comprehensive or holistic way, it becomes possible to state that the spiritual aspect takes precedence in the way that authors emphasise this aspect. To this extent the spiritual or religious aspect is not only upheld as the determining factor that shapes AIC members' view of the world and by implication their understanding of development (Adogame 2016, 1-3, 7-10; Bompani 2015, 110; Bompani and FrahmArp 2010b, 3; Öhlmann et al. 2016, 9, 2017, 9), but is also credited as the determining factor, through the 'transformations of subjectivity' (Freeman 2015, 117), that brings about AIC members' (noticeably from the PCCs) tangible social and economic upward mobility (Bernstein and Rule 2010, 104-105, 122-127; Freeman 2015, 119-123; Garner 2000, 315, 324, 329, 337; Schlemmer 2008, 78-79, 80-83, 86-87).

It does not come as a surprise, therefore, that a strong challenge to the metanarratives of mainstream (western) development theory and its underlying thesis of secularisation emerges in the selected literature. While more pronounced in some contributions but nevertheless also implied in others, the call is for rethinking the nexus between religion and modernity based on the accumulating research evidence about AICs in the development sphere. Based on the new evidence from below, most often in contexts where the state has not met the desired expectations as a development actor, the thesis advanced is of AICs and religion as constructive agents of a kind of modernity in which religion and religious faith are not antithetical to development and progress (Bompani 2010, 2015; Bompani and Frahm-Arp 2010b, 2010c). Moreover, this could be understood as a kind of modernity that is not antithetical to the ideals of modern democratic capitalism (Bernstein and Rule 2010; Freeman 2015; Garner 2000; Schlemmer 2008), but operates within an alternative meta-theoretical framework that allows for the possibility of multiple or plural conceptions of modernity (Bompani and Frahm-Arp 2010c, 247-249).

\section{Development from below as a counterpoint to development from above and concomitant state failure}

This chapter has already alluded to the way in which development from below and development from above are projected as two major contrasting images or ideas in the selected literature on AICs and development. Thus, not unlike its counterparts in the literature on an alternative development paradigm 
highlighted earlier, in the selected literature a rather extensive range of actors and forces can be identified that are associated with the dynamics of development from above. More pointedly, this includes reference to the World Bank, International Monetary Fund (IMF), United Nations Development Programme, the apparatus of western-led development, the European Enlightenment, structural adjustment programmes, colonialism (Adogame 2016, 1-3; Bompani 2015, 101, 103) and even the Human Development Index (HDI), NGOs and development scholars of a particular kind (Adogame 2016, 2-4), as well as macroscale economic development approaches (Freeman 2015, 114).

Yet while these actors and forces can all in one way or another be related to the failures in bringing about authentic development for poor people and communities on the ground (cf. Garner 2000, 315; Schlemmer 2008, 9), one of the outstanding theoretical claims in the selected literature is that the state - or for some more specifically 'the post-colonial "developmental" state' (Garner 2000, 315 ) - stands at the helm of those development failures. As such, what emerges from this theoretical claim is a particularly negative view of the African state plagued as it is by wide-scale corruption, an inability to deliver services, or to create employment and combat crime (Bompani 2010, 313, 2015, 103; Bompani and Frahm-Arp 2010b, 6-7; Schlemmer 2008, 83) - as by and large incapable of meeting the legitimate development aspirations of its citizens on the ground.

A pessimistic view consequently prevails in the selected literature about the prospects of the state being able to transform itself into a more reliable and viable agent of grass-roots development (Garner 2000, 315; Schlemmer 2008, 9; Bernstein and Rule 2010, 126; Bompani 2010, 313, 2015; Adogame 2016, 7). The inclination is therefore to go beyond hope that the state will deliver and, based on empirical evidence, commend the way in which AICs acting in people-oriented organisational mode generate self-help and self-development initiatives (Bompani 2010, 321; Schlemmer 2008, 7, 83-85; also Adogame 2016, 7; Bompani 2015, 103). This promotes an image of AICs' ability 'to reach where the state cannot' (Bernstein and Rule 2010, 126; cf. Bompani 2015, 104; Öhlmann et al. 2016, 7; Schlemmer 2008, 83-85) by promoting a new sense of agency, ownership, and self-esteem among its members (Bernstein and Rule 2010, 104-105, 126; Bompani 2010, 314-315; Freeman 2015, 117-119).

It is also in relation to this dimension of the development-from-below thesis that a perspective on AICs as being at the centre of a dynamics of slow but independent and steady upward mobility again emerges. For authors from the selected literature, writing in the wake of evident state inability and outright state failure, this dynamic is manifested through numerous examples of smallscale, grass-roots activities that involve different target groups (such as youths and women) and span across the different spheres of social, economic and spiritual life. In terms of an even more concrete identification, it includes activities and initiatives directed at meeting immediate survival and welfare needs, pastoral counselling, HIV and AIDS care, rehabilitation from substance abuse, health services, youth empowerment and recreation, primary, secondary, and tertiary education, entrepreneurship, financial empowerment and skills development, 
and social housing (Adogame 2016, 7-11; Bernstein and Rule 2010, 102-104, 106, 123-126; Bompani 2010, 309-310, 314-320; 2015, 103; Freeman 2015, 120; Öhlmann et al. 2016, 6-8, 2017, 7).

Finally, a provocative but worthwhile interpretation from the selected literature on AICs' central position in the move away from state dependence to selfreliance is thus that 'religion' could be perceived as surpassing 'politics in the search for the better life' (Schlemmer 2008, 83). For Lawrence Schlemmer, this perception at least seemed real for those persons who were interviewed both in the townships and in the suburbs of South Africa, suggesting 'that religion had achieved far more in improving lives and morale than have the political programmes and promises' they (i.e. the interviewees) encountered (ibid.). Effectively, this finding therefore testifies to a group of people for whom the state and the political dynamics associated with it play a very insignificant role in the way that they strive to live their lives meaningfully:

In the survey results we were surprised at how little impact political disillusionment seemed to have on personal morale among believers as opposed to non-churchgoers.... Religious commitment in general imparts a buoyant mood and spiritual 'capital' seems to be correlated with social capital, confidence, patience and fortitude. Religion seems to insulate people from political and economic stress even without 'other worldly' seclusion or fatalism... [A]ll categories of churchgoers reflected sentiments of selfreliance - a critical finding in view of the mass dependence on state support in the population at large.

(ibid., 84) $)^{1}$

\section{Development from below as a political dynamic}

For at least some proponents of the development-from-below thesis, the reality of religion's superior contribution to the well-being of AIC members does not, however, imply an apolitical stance in AIC conscience and engagement. Thus, in contrast to an interpretation that goes so far as to associate AICs and their members with such a stance or at most with a limited 'influence in public affairs' (Bernstein and Rule 2010, 116), an argument advanced is that a political dimension is indissolubly part of the dynamics of development from below associated with AICs. As a result, what comes to the fore is a clear conceptual overlap suggested by the use of phrases such as 'politics of development from below' (Adogame 2016) and 'politics and development from below' (Bompani and Frahm-Arp 2010a, 2010b), as well as applications of the catchphrases 'development from below' (Bompani 2010) and 'politics from below' (Bompani 2008) to the same empirical research.

In terms of a more specific claim to the political, then, one could start with Adogame and Bompani's rather similar rendering of political meaning according to the way AICs exert themselves as deliverers of social services to their members. With reference to the example of the Redeemed Christian Church of 
God (RCCG) in Nigeria, for Adogame $(2016,7)$ the RCCG's increasing acceptance of 'extra-religious functions such as social welfare programmes' could be taken as an example of a church that engages itself in the 'public sphere' and makes a contribution where other constituencies ${ }^{3}$ are noticeably failing. And for Bompani (2010, 321), based on her research in the suburb of Jabulani in Soweto, South Africa, the engagement of AICs of the African Independent type in the social sphere could likewise be interpreted as 'political in the way they concern themselves pragmatically with local community issues like housing unemployment, health care, and education'. In the context of Bompani's overall argumentation, these are issues that not only expose the neglect and failure of the post-apartheid state, but at the same time highlight the significance of AICs as local actors challenging this neglect and failure through their active concern with the social well-being of their members (ibid., 312-322).

It should be conceded at this point that one effectively remains confined to the contributions of Bompani for a further elaboration of the political perspective in the selected literature. While she largely has to depend on her already mentioned ethnographic research in South Africa to advance her argument, the way in which she uses her empirical findings to challenge conventional apolitical interpretations of the AICs is nevertheless significant. For Bompani, it becomes essential to adopt 'an alternative approach' to 'religion and politics' (Bompani 2008, 674). When considering the case of the AICs in the post-apartheid context in particular, she contends that such an approach should lead one to challenge a number of traditional assumptions: that the political effectiveness of AIC leaders should be measured in the light of their public outspokenness at the national level (ibid., 671); that any visible political inclination among AICs should be related to 'institutionalised components of politics like party organisations' (ibid., 677); and that silence should necessarily be equated with withdrawal from politics (ibid., 669).

It follows that for Bompani, also when reflecting with her fellow author Maria Frahm-Arp on an African reality that goes beyond the South African context, it becomes fundamental to gain a deeper insight into what happens on the local level in order to properly appreciate AICs' political significance (ibid., 666, 671; Bompani 2010, 310, 314, 321; Bompani and Frahm-Arp 2010b, 3; 2010c, 244-246, 248). Based on her own empirical findings, but also on the wider accounts of empirical and theoretical insights that she draws upon with Frahm-Arp, different layers of interpretation emerge.

The first is an interpretation that far from typecasting AICs as depoliticised entities, appreciates them as reservoirs of 'cultural autonomy' and 'moral authority' within a larger and often turbulent societal dynamics (Bompani and FrahmArp 2010c, 245). Accordingly, the implication here is that AICs' apparent withdrawal from formal politics as well as their independent stance vis-à-vis the state, government and mainstream development agencies could be interpreted as a political act in itself. Through such distancing they not only guard their members from the divisive and corruptive influences of political organisations (Bompani 2008, 666-670; Bompani and Frahm-Arp 2010b, 7; 2010c, 246), but 
shielded from such influences also function as independent spaces, where 'the potentiality of self-development, freedom and self-empowerment' are developed (Bompani 2010, 321; Bompani and Frahm-Arp 2010c, 245; cf. Bompani 2015, 105-106).

From the vantage point of such a position of independence a second layer of interpretation also gives evidence of a more overt critical political conscience and engagement on the ground. Beyond the surface of apparent withdrawal, the picture gained particularly from Bompani's South African research is one where religion and politics meet far more purposefully in the lives of AIC members. In the post-apartheid context of Jabulani in Soweto, she contends, politics remains 'a fundamental component of social interaction and discourse', a reality from which the churches in this township can also not escape, given their members' own experiences of 'the rigours of apartheid' (Bompani 2008, 670).

Key to Bompani's argument, then, is that AICs in Jabulani constitute an indissoluble part of the aforementioned political dynamics. By drawing on her own participatory observation, for her one of the most significant starting points was to visit the different liturgical events of these churches. Since it was at these events that a political conscience was clearly cultivated among church members as part of the religious discourse and performance. In the words of Bompani that recall one case in point of her common experience across events she attended:

In attending churches in Soweto, I perceived that politics emerged spontaneously from everyday religious settings, observances and discourses. Being at the liturgy on Sunday at Jabulani meant also debating the nationbuilding process and discussing corruption, unemployment and government... On Sunday 9 December 2001, the reading inspired Bishop Ntongana to talk of social justice and urged his listeners to fight for their rights. Referring to the stagnant conditions of poverty in the township ... Ntongana addressed the audience thus: 'Fight for your rights, fight for justice, because there cannot be peace without justice and no reconciliation without peace. How can we forgive for the past if we keep suffering now? Things have to change.'

(ibid., 674-675)

It can be concluded here that the reality presented by Bompani is therefore far from a non-political one. Instead, it is a reality where 'political activism and public roles' (ibid., 671) were enacted from a position of political independence visible at the local level through the way in which AIC leaders, but also other church members, took the lead in instilling and cultivating a critical awareness among their members. Almost a decade after apartheid (i.e. at the time of Bompani's research), such outspokenness was directed at issues of state neglect, such as lack of service delivery, but also at the need for AIC members to claim their rights as citizens in the new democratic dispensation (ibid., 671-677; cf. Bompani 2010, 312-314). This activism, however, significantly extended beyond AIC liturgical events to more overt public action, as for instance 
illustrated by two examples: a march against crime that was organised by local Independent Churches and a report that was drafted by a regional meeting of the Council of African Instituted Churches (CAIC) held in October 2001 in Jabulani for submission to the local authorities. The latter document, Bompani significantly summarises, 'emphasised the unacceptable level of poverty in the communities, citing social injustice and inequitable wealth distribution... as the major causes' (ibid., 671-672).

\section{Development from below as social change from below invigorated by radical personal transformation and a remaking of the Protestant ethic}

This chapter, in its discussion of a first dimension of the development-frombelow thesis, has already alluded to authors' appreciation of the role of spiritual life and related personal transformation as a most important causal factor in the dynamics of development from below. In terms of what could otherwise be defined as AIC members' devotion to a life of exceptional faith commitment, this element is given further substance and direction in the selected literature to the extent that it could rightfully take its place as a distinguishable fourth dimension of the development-from-below thesis. In particular, this pertains to the way in which a number of authors portray the distinguishable features of personal transformation and high faith commitment - specifically with regard to AICs of the Pentecostal variant - as not only conducive to but in fact also manifesting a remaking of the Protestant ethic famously theorised by sociologist Max Weber (Bernstein and Rule 2010, 95-96; Freeman 2015, 123; Garner 2000, 311, 329; Schlemmer 2008, 22, 86, 81).

This claim of a 'remaking' of the Protestant ethic is directly linked to an appreciation of contemporary Pentecostalism as being at the centre of 'a new wave of Protestantism' (Bernstein and Rule 2010, 95), which in turn also holds new significance for the Weberian thesis. This implies that Protestant Churches of mainline descent have largely lost their social and ethical influence in contemporary society. In contrast to this decline, however, Pentecostal Churches are held in high esteem for their popular appeal and many features that fit Weber's description of the Protestant ethic (Bernstein and Rule 2010, 95-96; Garner 2000, 312-316, 329, 335-337; Schlemmer 2008, 22, 24-25). This is seen by the authors from the selected literature as a development that is as pertinent to the religious landscape of African societies as it is to other parts of the world.

While the aforementioned strongly features as a perspective on African PCCs and development from within the South African context in the selected literature (Bernstein and Rule 2010; Garner 2000; Schlemmer 2008), this perspective is also given a broader framework through Dena Freeman's (2015) important contribution 'Pentecostalism and economic development in subSaharan Africa'. In this part of the world, Freeman $(2015,115)$ asserts, there has been nothing less than a 'Pentecostal explosion' whereby 'millions of people 
... have joined Pentecostal churches'. But beyond such numerical significance, for Freeman, in the context of an argumentation about development, of special significance has been Pentecostalism's ability to resonate with the African worldview more than other forms of Christianity have been able to do.

Pentecostalism shares the basic ontology of good and bad spirits, and embraces supernatural beings (God, Jesus, demons) that can have a direct influence in the world.... In this way Pentecostalism becomes a lot more meaningful and powerful to Africans than earlier forms of Christianity. And in this power we find an astonishing ability to bring about change and transformation - often in the direction of what we usually call 'development'.

(ibid., 116-117)

Having introduced the topic of development in this way, Freeman makes the crucial point that the strength of African PCCs' contribution does not lie in the number of development projects they have been initiated. PCCs in Africa, she observes, have rather been slow 'in setting up "development wings" and joining in with explicitly development-focused activities' (ibid., 116). In contrast to this lack, however, a key point of her argument is that African PCCs' greatest contribution to development is made through what has already been captured in this chapter as the ability to bring about transformations of subjectivity - a remaking of the individual, the whole person. As she elaborates:

By far the greatest impact that Pentecostals have on development in Africa comes ... from the changes instilled in 'believers' by the religious activities of the churches themselves. In these churches 'religion' is not separated from 'development'. Church leaders take a holistic focus on the 'whole person' and try to bring about change socially and economically, as well as spiritually.

(ibid, 116-117)

For Freeman, as for the other authors referenced above, what is at stake in African Pentecostal faith is nothing less than a radical personal transformation of its followers. Of special importance, this is a kind of transformation whereby such individuals experience a new sense of freedom from past captivities (evil spirits, costly traditional practices, mental attitudes of hopelessness, and despair) that in turn leads to a new sense of empowerment, self-worth, confidence, optimism, and agency to grasp opportunities when they come about. What is implicated is not only a radical change in mental attitude, but also a kind of behaviour that is characterised by moral discipline and a particular value orientation. This includes a new devotion on the part of believers to a frugal, disciplined lifestyle characterised by hard work, educational improvement, changed consumption patterns, and abstinence from alcohol, tobacco, and extramarital relationships (Bernstein and Rule 2010, 98-106, 111-117, 122-127; Freeman 2015, 117-119, 121-123; Garner 2000, 325-9; Schlemmer 2008, 45-52, 59-64, 70-72, 75-87). 
Consequently, it is not difficult to grasp why for this specific group of authors contemporary African Pentecostalism displays features that relate favourably to the Weberian thesis. For them, contemporary African Pentecostalism and its associated ecclesial formations fall nothing short of being a new vibrant movement that holds huge potential for large-scale social and economic development from below (Bernstein and Rule 2010, 122-127; Garner 2000, 337; Schlemmer 2008; cf. Freeman 2015, 115-116, 123). Hence, it is a movement driven by the same kind of 'this-worldly asceticism' (Bernstein and Rule 2010, 105; Schlemmer 2008, 61, 81, 86) that Weber identified and, through the aforementioned attributes, is put into service of the desire for material and economic improvement. By implication, it is an orientation founded on the belief that salvation 'can take place in this life' (Freeman 2015, 120), which in turn explains the visible entrepreneurial drive in many PCCs stimulating business behaviour among their members and encouraging them to start businesses (Bernstein and Rule 2010, 98, 102-103, 106, 108-111, 125-126; Freeman 2015, 120; Schlemmer 2008, 33, 76, 78).

In concluding this brief account of how a claim to personal transformation and a closely related remaking of the Protestant ethic stands central to the identification of a fourth dimension of the development-from-below thesis, it seems worthwhile to quote Freeman again, this time her own concluding appreciation of Pentecostalism's contribution to such a dynamic and by implication development from below in African society. Provocative in the way in which a favourable connection is drawn between the Pentecostal contribution and the demands of neoliberal capitalism, Freeman concludes:

In The Protestant Ethic and the Spirit of Capitalism, Weber ... argued that there was an elective affinity between the spread of Protestant Christianity and the growth of capitalism in sixteenth- and seventeenth-century Europe.... While there are many differences between sixteenth-century Calvinism and twenty-first-century Pentecostalism ... there are nonetheless also many parallels, and I have sought to show here how Pentecostalism plays a similar role in Africa today. It is a form of Protestantism that stimulates a transformation of behaviour that can lead to success, or at least upward mobility, in the contemporary neoliberal economy. It motivates new behaviours and renders them moral. It promotes hard work, saving and limitation on certain types of unproductive consumption. Thus it leads people to participate, and succeed, in the capitalist economy. This, at least in present thinking, is what we generally mean by development.

$(2015,123)$

\section{Development from below as an acknowledged capacity to generate social capital}

In the selected literature, not surprisingly one could say, several authors also draw strongly on the notion of social capital to describe AICs' strength as 
actors in the dynamics of development from below. This provides the grounds for the identification of a fifth and last dimension of the development-frombelow thesis, an identification that could begin with Bompani's (2010, 322) statement at the end of one of her writings claiming 'that AICs have an acknowledged capacity to generate social capital and thus to mobilise their adherents' (italics added). By implication, therefore, for Bompani this capacity or ability of AICs is not merely something that was revealed by her own research in Jabulani, Soweto, but it represents a more general or broader acknowledgement of AICs' essential nature and ability that becomes evident in a number of ways:

through the great attention given to trust and community relations; through the important role played by the leadership; through local roots and sources of accountability; through a commitment to values compatible with democratisation, good governance, and other forms of sustainability, as well as participation.

(ibid.)

Clearly, then, Bompani's claim to an acknowledged capacity of AICs to generate social capital also reverberates in several other contributions to the development-from-below thesis forming part of the selected literature in this chapter (Adogame 2016, 4; Bernstein and Rule, 2010, 105, 116, 122; Bompani, 2008, 666; 2015, 106; Öhlmann et al. 2016, 4, 9; Schlemmer 2008, 45, 49, 53-54, 84, 89). The contribution by Adogame, for instance, catches one's attention for the way in which he draws upon the well-known conceptual distinction between 'bonding', 'bridging', and 'linking' social capital. Based on his ethnographic research on the RCCG, Adogame advances the argument that the RCCG generates social capital through its local (Nigerian) and international institutional formations. He explains how this formation of social capital starts in the spaces of worship, where numerous forms of socialisation and relationship building take place, but also how it manifests through many initiatives for the social and economic betterment of church members and other people (noticeably also in diaspora contexts) (Adogame 2016, 7). ${ }^{4}$

Thus, one could derive from Adogame's distinctive social capital claim - but also from similar assertive claims by the other authors referenced above - that it is AICs' ability or capacity to generate social capital that ought to be appreciated as the foremost means that enables them to present themselves as a force for advancing development from below. These churches, it is postulated, 'are networks of mutual support undergirded by strong bonding forces and high degrees of trust' (italics added) (Öhlmann et al. 2016, 4; cf. Adogame 2016, 11; Bernstein and Rule 2010, 105, 116; Bompani 2008, 666; 2010, 317; 2015, 106). Consequently, it is this cooperative and relational quality that not only explains AICs' involvement in many concrete activities related to the needs of their members (Öhlmann et al. 2016, 6-7) but also determines the specific " "developmental" ethos' of those activities. Bompani $(2015,106)$ explains: 
Their 'developmental' ethos is particularly evident with the promotion of communities' initiatives and the sustainment of their own improvement through local techniques like protection from evil spirits ... the promotion of strong networks for community support and the running of traditional financial schemes of assistance in poor economic situations.

In drawing this section of the discussion to a close, it however becomes necessary and important to also point to a more complicated picture in the overarching claim to AICs' capacity to generate social capital. Thus, whereas a common claim has been depicted above that assumes the inclusion of both variants of AICs focused upon in this chapter, this more complicated picture pertains to the differences that could be highlighted when dealing with more concrete issues and examples in the selected literature. This first concerns the identification of savings clubs and burial societies as prominent manifestations of AICs' social capital capacity in the contributions by Bompani (2010, 310, $316-320 ; 2015,106)$ and the Berlin group of Öhlmann et al. (2016, 4), respectively. Whereas it becomes clear in Bompani's case that these two examples pertain to AICs of the African Independent-type variant, this differs in the case of the Berlin group's identification of saving clubs and burial societies as practices that feature in both groups of churches.

Finally, the second difference this chapter finds important to highlight takes on additional significance for relating to the political dimension of the development-from-below thesis. More specifically, it concerns the way in which the contradiction between apolitical and political interpretations of AICs' social involvement alluded to in that section of the discussion comes to the fore in the claims made about the social capital dimension in the contributions particularly of Bompani (2008, 2010) and Bernstein and Rule (2010).

In the case of Bompani, her focus is confined to a group of AICs of the African Independent variant in a local South African context. Her appreciation is here indissolubly linked to her political interpretation discussed earlier and basically projects the idea that it is those AICs' capacity to generate social capital that generates their particular dynamics as political actors on the ground. In this respect, she adopts, in social capital mould, the notion of 'a network of solidarity' to describe how those churches are fighting for the proper social rights of their members, 'such as education, health, knowledge about HIV, economic support, and housing' (Bompani 2010, 114; see also Bompani 2008, 666).

Yet, in comparison to Bompani, Bernstein and Rule's contribution can be contrasted not only for its distinctive focus on AICs of the Pentecostal variant, but also for relating the latter's capacity to generate social capital to what they perceive as Pentecostals' (albeit Pentecostals confined to the South African context) limited influence in the public realm. For these two authors, while this lack of political or public involvement may be seen as a prevailing weakness, they nevertheless celebrate the fact that 'Pentecostals have "social capital" on their side' (Bernstein and Rule 2010, 116); that is, social capital of the degree 
and quality that will continue to enhance their profile as a social and moral force despite the lack of direct political involvement (Bernstein and Rule 2010, $116,122,126)$.

\section{African Initiated Churches and the development-from-below thesis: promises, challenges, and limitations}

This chapter began by postulating how development from below has come into vogue as a distinctive theoretical claim or thesis in the research focus on AICs and development in the academic literature. Based on closer scrutiny of this postulation, one is left with the impression that this thesis is already giving important direction to the research focus on AICs and development. To the extent that the thesis could even be regarded as a dominant idea emanating from this focus, in this chapter five dimensions (one could also call them five thematic areas) have been identified that can be said to constitute promising avenues for an ongoing systematised research undertaking on AICs and development, both from a theoretical and an empirical point of view. Taken together, the five dimensions cannot represent a complete research agenda, but rather a comprehensive agenda that touches on areas that are all crucial to religion and development as a distinctive subject field, namely:

- development from below as a desecularised catchphrase or idea;

- development from below as a counterpoint to development from above and concomitant state failure;

- development from below as a political dynamic;

- development from below as social change from below invigorated by radical personal transformation and a remaking of the Protestant ethic;

- development from below as an acknowledged capacity to generate social capital.

The undertaking in this chapter has also proved to be meaningful in the way that it has at least partly validated an operational definition that categorises both the familiar African Independent-type Churches and African Pentecostal Churches (PCCs) under the umbrella term African Initiated Churches. This has been shown in the way in which both groups of churches are related to the development-frombelow thesis - in other words, presented as actors in the dynamics of development from below. Within this ambit, while the five dimensions identified could rightly be regarded as cross-cutting essential dimensions that define the development-frombelow thesis in the selected literature, their identification and exploration in this chapter also highlight the need for further in-depth research. In particular, here the author of this chapter has in mind a research undertaking that would from the vantage point of an even more representative African focus, ${ }^{5}$ deepen its exploration along the thematic lines developed in this chapter. As a direct consequence, this undertaking should necessarily incorporate more nuanced subcategorisations of African Initiated Churches taking greater cognisance of the diversities within 
both the African Independent and Pentecostal (PCC) variants, such as urban and rural churches and churches of different sizes. But of no lesser importance, such undertaking should also open new possibilities for empirical testing and verification, not least of the contrasting perspectives or emphases that have surfaced from the analytic undertaking in this chapter. In so far as these contrasting perspectives or emphases reflected specifically in the discussions of the third, fourth, and fifth dimensions of the development-from-below thesis, this could be considered the way in which:

- Development from below as a political dynamic (third dimension) has been associated with AICs of the African Independent type through the work of Barbara Bompani (in some instances also with her fellow author Maria Frahm-Arp), while with the exception of one contribution (Adogame) a similar association did not reflect in discussions of AICs of the Pentecostal variant (PCCs).

- Development from below as social change from below invigorated by radical personal transformation and a remaking of the Protestant ethic (fourth dimension) has been associated by the relevant authors as a feature of Charismatic Pentecostalism, while a similar association did not reflect in any discussion of AICs of the African Independent type.

- Development from below as an acknowledged capacity to generate social capital (fifth dimension) has been described as functional within the political inclinations of AICs of the African Independent type (Bompani), while PCCs' capacity to generate social capital has been juxtaposed with their apolitical inclinations in at least one contribution from the selected literature.

In its final conclusion, this chapter importantly finds a need to also go beyond its statement on promises and challenges by arguing that there may be important limitations in a research focus on AICs and development that is directed exclusively by the development-from-below thesis. This stance has relevance especially when one becomes willing to take account of and learn from the development studies literature in which scholars also engage more critically with the development-from-below idea, including work dealing more pointedly with the notion of social capital. In a nutshell, in this sphere of theorising the argument advanced is that in as much as problems of development cannot be solved by top-down strategies of development, it is equally unrealistic to think that they can be solved by a bottom-up approach to development (see e.g. Brohman 1996, 270-276, ch. 11; Friedmann 1995, ch. 7; Sanyal 1998; Stöhr 1980; Woolcock 1998; Woolcock and Narayan 2000). To quote Sanyal (1998, $8,11)$ at some length again, as he captures this theoretical position's counterargument for adopting a synergistic approach (cf. Woolcock 1998; Woolcock and Narayan 2000, 235-239) particularly well:

What is the record of NGO-led, bottom-up development efforts? Nearly twenty-five years and thousands of projects later, the economic impact of 


\section{Ignatius Swart}

bottom-up efforts seems rather small and insignificant.... Although the bottom-up approach was distinctly anti-state in orientation, and was based on the premise that as agents of development from below NGOs should avoid working with the state and other dominant institutions at the top, in reality the experience of relatively successful NGOs indicates that they had worked fairly closely with the government and market institutions.... This finding suggests a reconsideration of development strategy from its preoccupation with either 'trickle down' or 'bottom-up' development. It indicates that, just as development does not trickle down from the top, neither does it effervesce from the bottom. Development requires a synergy between institutions at the top and the bottom, a collaborative effort involving the state, market, and civil society. Action in any one domain alone, however well intended, is not adequate for broad-based development.

This chapter finally concludes by upholding the synergistic approach as an important, if not crucial, pointer for ongoing theory building not only in the research focus on AICs and development, but in fact the field of religion and development as a whole. Clearly, without doing so, there is the real danger of succumbing to what Jones and Petersen (2011, 1296-1300) have so importantly highlighted as the tendency to become overtly instrumental, narrow and normative by assigning strengths and qualities to religious organisations that are overstated if not misplaced in situations of great developmental complexity. But to this one could also add the dangers of isolation, essentialism, and absolutism, whereby the wider landscape or architecture of development is basically ignored, including other actors whose ideas and practical worlds are similarly shaped by normative frameworks for development.

\section{Notes}

1 The limitation of confinement to a South African perspective for drawing more generic conclusions is recognised here. Nevertheless, favourable comparisons can be drawn between Schlemmer's description of AIC mental outlook in the South African context and descriptions elsewhere in the selected literature, such as by Adogame (2016, 7), of members of the Redeemed Christian Church of God's social and spiritual inclinations in Nigeria, and by Freeman $(2015,117-120)$ of Pentecostal subjectivity across different African locations.

2 Adogame continues to discuss in greater detail the RCCG's establishment of structures (programmes) to combat HIV and drug use/abuse among young people (2016, 7-10).

3 In a more generalised manner, with reference to the larger African context and African diaspora, Adogame $(2016,7)$ alludes to the deterioration of 'constituencies such as governments, trade unions ... [and] blue-collar workplaces'.

4 Cf. n. 3 above and the corresponding main text in this chapter.

5 Here one may recall this chapter's early acknowledgement about its reliance on a corpus of material strongly dominated by contributions from the South African context and the consequent need to expand the present exploration towards a more representative African focus. 


\section{References}

Adogame, Afe. 2016. 'African Christianities and the Politics of Development from Below.' HTS Theological Studies 72, no. 4: 1-11. http://dx.doi. org/10.4102/hts. v72i4.4065

Bernstein, Ann, and Stephen Rule. 2010. 'Flying under South Africa's Radar: The Growth and Impact of Pentecostals in a Developing Country.' In The Hidden Form of Capital: Spiritual Influences in Societal Progress, edited by Peter L. Berger, and Gordon Redding, 91-131. London: Anthem Press.

Bompani, Barbara. 2008. 'African Independent Churches in Post-Apartheid South Africa: New Political Interpretations.' Journal of Southern African Studies 34 (3): 665-677.

Bompani, Barbara. 2010. 'Religion and Development from Below: Independent Christianity in South Africa.' Journal of Religion in Africa 40, no. 3: 307-330.

Bompani, Barbara. 2015. 'Religion and Development in Sub-Saharan Africa.' In The Routledge Handbook of Religions and Global Development, edited by Emma Tomalin, 101-113, London: Routledge.

Bompani, Barbara, and Maria Frahm-Arp, eds. 2010a. Development and Politics from Below: Exploring Religious Spaces in the African State. Basingstoke: Palgrave Macmillan.

Bompani, Barbara, and Maria Frahm-Arp. 2010b. 'Introduction: Development and Politics from Below: New Conceptual Interpretations.' In Development and Politics from Below: Exploring Religious Spaces in the African State, edited by Barbara Bompani and Maria Frahm-Arp, 1-19, Basingstoke: Palgrave Macmillan.

Bompani, Barbara, and Maria Frahm-Arp. 2010c. 'Conclusion: Reflections on Modernization without Secularization.' In Development and Politics from Below: Exploring Religious Spaces in the African State, edited by Barbara Bompani and Maria Frahm-Arp, 240-251, Basingstoke: Palgrave Macmillan.

Brohman, John. 1996. Popular Development: Rethinking the Theory E Practice of Development. Oxford: Blackwell.

Carmen, Raff. 1996. Autonomous Development. Humanizing the Landscape: An Excursion into Radical Thinking and Practice. London: Zed Books.

Freeman, Dena. 2015. 'Pentecostalism and Economic Development in Sub-Saharan Africa.' In The Routledge Handbook of Religions and Global Development, edited by Emma Tomalin, 114-126, London: Routledge.

Friedmann, John. 1995. Empowerment: The Politics of Alternative Development. Cambridge, MA: Blackwell.

Garner, Robert C. 2000. 'Religion as a Source of Social Change in the New South Africa.' Journal of Religion in Africa 30, no. 3: 310-343.

Jones, Ben, and Marie Juul Petersen. 2011. 'Instrumental, Narrow, Normative? Reviewing Recent Work on Religion and Development.' Third World Quarterly 32, no. 7: 1291-1306. http://dx.doi.org/10.1080/01436597.2011.596747

Korten, David C. 1990. Getting to the 21st Century: Voluntary Action and the Global Agenda. West Hartford: Kumarian Press.

Meyer, Birgit. 2004. 'Christianity in Africa: From African Independent to PentecostalCharismatic Churches.' Annual Review of Anthropology 33 (2004): 447-474. https:// doi.org/10.1146/annurev.anthro.33.070203.143835

Öhlmann, Philipp, Marie-Luise Frost, and Wilhelm Gräb. 2016. 'African Initiated Churches' Potential as Development Actors.' HTS Theological Studies 72, no. 4: 1-12. http://dx.doi. org/10.4102/hts.v72i4.3825 


\section{Ignatius Swart}

Öhlmann, Philipp, Marie-Luise Frost, and Wilhelm Gräb. 2017. 'African Initiated Churches and Sustainable Development in South Africa - Potentials and Perspectives.' Religion \& Development 01/2017. Discussion Paper Series of the Research Programme on Religious Communities and Sustainable Development. Berlin: Humboldt-Universität zu Berlin.

Rahman, Md. Anisur. 1993. People's Self-Development: Perspectives on Participatory Action Research. London: Zed Books.

Sanyal, Bishwapriya. 1998. 'The Myth of Development from Below.' Paper presented at the Association of Collegiate Schools of Planning, Annual Conference, Pasadena, CA, November 1998.

Schlemmer, Lawrence. 2008. Dormant Capital: Pentecostalism in South Africa and its Potential Social and Economic Role. Johannesburg: Centre for Development and Enterprise.

Stöhr, Walter. 1980. 'Development from Below: The Bottom-Up and Periphery-Inward Development Paradigm.' IIR-Discussion Papers 6. WU Vienna University of Economics and Business, Vienna.

Woolcock, Michael. 1998. 'Social Capital and Economic Development: Towards a Theoretical Synthesis and Policy Framework.' Theory and Society 27 (2): 151-208.

Woolcock, Michael, and Deepa Narayan. 2000. 'Social Capital: Implications for Development Theory, Research, and Policy.' The World Bank Research Observer 15, no. 2: 225-249. 